DOI https://doi.org/10.36059/978-966-397-158-2/41-66

\title{
INFORMAL DESTRUCTIVE POLICY PRACTICES AS A FACTOR OF INFLUENCE ON DEMOCRATIC POLITICAL TRANSIT
}

\section{Krasnopolska T. M.}

\section{INTRODUCTION}

Democratic political transit is a condition for constructive socio-political changes in society and the prevention of backward movement in which destructive political institutions and practices are involved.

Constructive socio-political changes imply the development of the political system of society, and both state institutions and mechanisms of their functioning, as well as elements of civil society. An important role in these processes is played by the establishment of interaction between the state and civil society, since only as a result of cooperation, that is, the introduction of the social partnership model of these elements of the system, positive changes are possible.

In our country, at the present stage of its development, both groups of political transit conditions are present.

The set of constructive socio-political changes necessary for political transit through democratization can be combined with the definition of «parity democracy». Using this model of democracy will be the key to successful democratic transit, requiring the improvement or creation of new formal institutions and mechanisms for their interaction at the state and nonstate levels, and the inclusion of constructive positive informal practices in the process. An effective mechanism for the introduction of parity democracy is an orderly system of international, regional and national structures of state and civic nature, whose activities are aimed at affirming the principle of parity in different spheres of social life and guaranteeing the implementation of the strategies and policies developed by them ${ }^{1}$.

However, among the factors that hamper the pace of democratic transit and threaten to return to an undemocratic political regime, the manifestation

\footnotetext{
${ }^{1}$ Кормич Л. І., Краснопольська Т. М. Основні напрями стратегії впровадження моделі паритетної демократії в сучасній Україні. Актуальні проблеми політики. 2018. Вип. 62. C. 16 .
} 
of destructive informal political institutions and practices plays a leading role. It is their analysis that should be discussed in detail.

\section{Informal destructive political practices: place and role in the political process}

In recent years, the informal component of the institutional process has intensified, as evidenced by numerous social, political and economic indicators. The destructive upheavals of recent decades in a number of countries are caused by a surge of informal political practices of a radical nature that tends to be political violence and is expressed in the practice of separatism, extremism, terrorism.

The study of informal political institutions and practices is the latest trend in political science, presented in the works of D. S. North (laid the foundation of neo-institutional theory), S. Levitsky and G. Helmke, V. Merkel and A. Croissant (identified the features of informal institutions in defective democracies), C. Patrushev (exploring the possibilities of neoinstitutionalism for political process analysis), etc.

Among the domestic researchers worth mentioning are the developments of M. Karmazina, I. Kushnaryov (proving the interdependence of informal institutionalization and political regime, the level of civil society, the steadiness of democratic traditions, etc.), Yu. Matsievsky (examines the role of corruption, clientelism, nepotism, favoritism, patronage in hybrid regimes), A. Mogylova (analyzes methodological problems of development of modern institutional theory), V. Popoglo (conceptualizes informal destructive institutions of politics, forms of their manifestation and defines mechanisms of counteraction to them), O. Stoyko (sees reasons for the development of destructive informal institutions in the weakness of formal and constructive informal ones), M. Chabannoy (proving the role of informal institutions in political regimes with a low level of democracy), T. Shevchenko (exploring informal institutions through the analysis of essential characteristics and features of informal politics), etc.

Some authors devoted their research to the analysis of the essence of certain forms of destructive informal institutions. Thus, corruption was studied by D. Botalov, K. Davydenko, G. Kohan, T. Mirzoev, I. Revak, favoritism - I. Didenko, S. Paramonova, kronism - O. Oliynyk, clan O. Babkin, M. Mikhalchenko, patron-clientelism - I. Kovalska-Pavelko, O. Polishchuk, Y. Teleshun, V. Shevchuk, nepotism - Y. Nisnevych and others. 
The current political process is a multidimensional phenomenon, involving a large number of actors who use a diverse arsenal of political practices and institutions to achieve their goals.

Political practices are a set of rules, traditions and norms of behavior adopted in a given society. According to D. Budko, political practices can be defined as the reproduction of laws, stereotypes, rules that determine the presence of a political institute, and its interaction with other institutions ${ }^{2}$.

The whole variety of political practices can be represented by their division into formal and informal ones. If the rules and regulations established at the state level are formal practices, then the definition of informal practices is not as straightforward. This is explained by the complexity of the interpretation of the term «informal» itself, as well as its interrelation with the formal elements of political institutions. The latter allows us to include traditions, moral norms, etc. in informal political practices.

More often than not, informal political practices mean the constantly reproduced stereotypical rules of interaction of policy-makers established and supported by socio-cultural regulators: values, political orientations, attitudes, rather than formal legal norms ${ }^{3}$. They aim at gaining public authority and / or increasing the resources of the policymaker. They compensate for the inefficiency of formal institutions and practices of society, integrate a coherent communicative space.

Informal practices are most characteristic of non-Western societies. They become a much-needed political tool in the stage of institutional transformation, during the crisis and the destruction of old institutions ${ }^{4}$. The presence of informal political practices in the society indicates that there are some contradictions, and the subjects of the political process cannot for objective reasons or do not want to go democratically.

Informal political practices and institutions can be both constructive and destructive. However, the classification proposed by G. Helmke and S. Levitsky, which involves four types of informal institutions on the basis of two criteria, is more informative: the degree of difference between the results of the activities of certain interconnected formal and informal

\footnotetext{
2 Будко Д. А. Политические практики взаимодействия органов региональной власти в современной России: дисс... канд. полит. н.: 23.00.02. Санкт-Петербург, 2014. С. 9. URL: https://disser.spbu.ru/disser2/disser/Dissertazija_BudkoDA.pdf.

${ }^{3}$ Подхомутникова М. В. Неформальные политические практики в современной России: субъекты институиионализации: автореф. дисс. на соискание уч. степени к-та полит. н.: 23.00.02. Краснодар, 2010. 27 c. URL: http://cheloveknauka.com/v/335868/a?\#?page=27.

4 Мамчуева Ф.Ю. Формальные и неформальные политические практики современного политического процесса. Историческая и сочиально-образовательная мисль. 2013. № 5(21). С. 153.
} 
institutions (convergent - essentially the same, or divergent) and the effectiveness of the relevant formal institutes (the degree of adherence to paper-based rules and procedures $)^{5}$.

Researchers identify the following types of informal institutions and related policy practices:

- additional - co-exist with and cooperate with formal institutions to make policy outcomes more effective; a set of rules, routines and procedures that facilitate decision-making and coordination of bureaucratic activity, uphold legal norms (so researchers relate the effectiveness of the US Constitution to a range of informal rules, common abeyances and expectations common to citizens);

- adaptive - inherently contrary to the spirit, but not to the «letter» of the written law (informal consultations on harmonization of legislative actions, group agreements, etc.);

- substitutes - exist in a poorly institutionalized environment of weak state power, but contribute to the achievement of policy results, which formal institutions have failed to implement («gentlemen's agreements», public spouses of self-defense, informal courts, etc.);

- competing - arise in conditions of systematic non-compliance with ineffective norms of formal institutions and structure the behavior of political actors in such a way that they are compelled to adhere to the established informal rules, in fact facing the threat of punishment for following formal laws (corruption, clientelinetics) ${ }^{6}$.

German researchers V. Merkel and A. Croissant call «damage» to liberal-constitutional, legitimate and legally established norms by informal institutions and political practices as a key characteristic of post-Soviet regimes. According to these authors, this «deformation» of political procedures and decision-making rules arises, first of all, from a combination of two factors that have roots in the pre-democratic past: the authoritarian inheritance of informal practices; the accumulation of the economic and political problems of the post-authoritarian system that have been transferred from the authoritarian phase. These factors create favorable conditions for

\footnotetext{
${ }^{5}$ Helmke G., Levitsky S. Informal Institutions and Comparative Politics: A Research Agenda. Perspectives on Politics. 2004. Vol. 2. Issue 04. P. 728 . URL: https://wcfia.harvard.edu/files/wcfia/files/883_informal-institutions.pdf.

${ }^{6}$ Helmke G., Levitsky S. Informal Institutions and Comparative Politics: A Research Agenda. Perspectives on Politics. 2004. Vol. 2. Issue 04. P. 728-730. URL: https://wcfia.harvard.edu/files/wcfia/files/883_informal-institutions.pdf. 
the illiberal transformation of political institutions, which is carried out informally and leads to the advantage of informal practices ${ }^{7}$.

Informal institutions are present in various spheres of public life - from domestic (exchange of handshakes, rules of communication) to economic (shadow markets). H. Helmke and S. Levitsky write: «the term «informal institute» is used to refer to an incredibly wide range of phenomena, including personal relationships, clientelism, corruption, clans and mafias, civil society, traditional culture and various legislative, judicial and bureaucratic norms» ${ }^{8}$.

This list can be supplemented by the proposed H.-J. Laut forms: croneyism, nepotism, clientelist parties, autocratic clicks. He refers the use of the threat of putsch or military force, practices of civil disobedience, etc. to particular types of informal institutions ${ }^{9}$.

The most well-known and common form of informal destructive political practices that hinders democratization is corruption. According to the National Institute for Strategic Studies, in the post-Soviet space in recent years, the so-called «full corruption cycle», which can be reflected in the following scheme, has become a prominent place in political corruption ${ }^{10}$ :

$\mathrm{B}-\Gamma-\mathrm{B} 1>_{\mathrm{B}}-\Gamma 1>_{\Gamma}$,

where $\mathrm{B}$ and $\mathrm{B}-$ power, $\Gamma$ and $\Gamma-$ money, $\mathrm{B} 1-$ a new, increased amount of power, $\Gamma 1$ - the amount of corruption accumulated as a result of the corrupt use of power levers. It is in this cycle that such forms of political corruption as corruption lobbying, corruption favoritism, corruption protectionism, secret financing of dubious political projects in terms of public needs are widely used; contributions to the correction of election campaigns in a customer-friendly direction, with subsequent repayment of government positions, etc.

R. Karklins highlights the following types of political corruption prevalent in post-communist countries:

1) corruption at lower levels of government (bribery, deliberate manipulation of regulatory standards, use of administrative checks to solicit);

\footnotetext{
${ }^{7}$ Меркель В., Круассан А. Формальные и неформальные институты в дефектных демократиях. Полис. 2002. № 2. С. 20.

${ }^{8}$ Helmke G., Levitsky S. Informal Institutions and Comparative Politics: A Research Agenda. Perspectives on Politics. 2004. Vol. 2. Issue 04. P. 727. URL: https://wcfia.harvard.edu/files/wcfia/files/883_informal-institutions.pdf.

${ }^{9}$ Lauth H.-.J. Informal Institutions and Democracy. Democratization. 2000. Vol. 7. № 4. P. 27-43.

${ }^{10}$ Циганов В. «Загроза політичної корупції у демократичних політичних режимах». Аналітична записка. Національний інститут стратегічних досліджень. URL: http://old2.niss.gov.ua/articles/882/.
} 
2) withdrawal of assets for selfish purposes (use of state-owned assets for personal purposes, expenditures in the course of ineffective implementation of state programs, illegal profit obtained in the course of non-transparent privatization agreements with state assets; malpractice in the field of public procurement, nepotism, clientelism when appointing candidates);

3) «seizure of the state» by corrupt networks, which means using political institutions as a tool of business or openly criminal purposes. This type includes deliberate methods of reducing political competition, manipulation of electoral processes (including by creating «black box offices» of election campaigns, black PR-technologies), corruption of the legal sphere, abuse of powers of supervisory or investigative bodies on a large scale, use of compromise as a tool of political struggle, corruption of the media) ${ }^{11}$.

It should be noted that the phenomenon of corruption has existed since ancient times, as evidenced by the etymology of the word «corruption». Popular in domestic science is the version according to which «corruption» comes from the Latin «corruptio», which meant «corruption, bribery» ${ }^{12}$.

There is another point of view, in particular, the Russian researcher G. Mishin believes that: «The Latin term corruptio comes from the two root words «cor» (heart, soul, spirit, mind) and «ruptum» (to spoil, destroy, corrupt). Therefore, the essence of corruption is not in bribery, corruptibility of public and other employees, but in violation of unity (disintegration, decay) of a particular object, including public authorities ${ }^{13}$.

The first approach involves existing forms of corruption that are directly related to bribery of officials.

Second, it gives a broader interpretation of the concept and identifies two forms of corruption: «hard» (overt) and «soft» (veiled).

Thus, along with such traditional forms of corruption as malpractice and bribery and undue gain, such manifestations as: the involvement of officials and civil servants in commercial activities for personal or corporate profit, the use of official position for the purpose of so-called «transfer» of public funds for further transfer to cash and theft in banks, the provision of benefits to «their people» using public resources, use of official position to influence

${ }^{11}$ Karklins R. Typology of Post-Communist Corruption. Problems of Post-Communism. 2002. Vol. 49. № 4. P. 24. URL: http://pdc.ceu.hu/archive/00001528/01/03Karklins\%5 B1\%5D.pdf.

12 Суханов В. А. Коррупция в органах государственной власти как глобальная проблема. Вестник МГИМО. 2013. № 4(31). С. 213.

13 Мишин Г. К. О теоретической разработке проблемы коррупции. Коррупция: политические, экономические, организачионные $u$ правовые проблемы. Ред. В. В. Лунеева. Москва: Юристъ, 2001. С 264. 
the media, for personal and collective gain; the use by civil servants of fake persons and relatives in commercial structures for the purpose of personal enrichment; use of official position for distortion, failure to provide or delay deadlines for issuing information, lobbying for decisions on the adoption of normative acts in narrow group interests; providing state financial and material resources to election funds of certain applicants ${ }^{14}$.

All of the above-mentioned acts of corruption are in one way or another related to bribery of officials. In this regard, they refer to so-called «cruel» or explicit corruption. However, not only manifest corruption is widespread in political practice, but also some which, in the opinion of some authors, refer to «mild» corruption. The latter include clan and tribalism, favoritism and nepotism, clientelism and patronage, lobbying, localism and other informal practices.

Let us analyze the above forms of informal destructive political practices. According to V. Rimsky's definition, corruption («cruel» corruption) is the benefit of one's position in the system of state power or of one's associated social status for selfish purposes, by any means and under any circumstances. It also refers to «any action that contributes to the decomposition of state power and public administration, the destruction of mechanisms that ensure the functioning of power structures in the public interest, in the formation and strengthening of mechanisms for their functioning solely in personal or corporate interests, as well as in the interests of very narrow social groups» ${ }^{15}$.

As for politics, they talk about political corruption. According to Y. Nisnevych, «political corruption is defined as the use by a person holding public office of his or her powers and rights, official position and status in the system of public authority, the status of a public authority he represents for the purpose of unlawfully obtaining a personal and/or group, including for the benefit of third parties, political gain (political enrichment) ${ }^{16}$. It can take the form of «hard» and «soft» corruption.

It is possible to distinguish the main features of political corruption, namely: the subjects of political corruption are public officials, local selfgovernment bodies, representatives of political and public organizations (parties, parliamentary factions, blocs, public organizations, etc.).; subjects

\footnotetext{
${ }^{14}$ Хутов К. М. Лоббирование, коррупция, монополизм: исследование криминогенного взаимовлияния. Преступность и коррупция: современные российские реалии: сборник научных трудов / под ред. Н. А. Лопашенко. Саратов: Сателлит, 2003. С. 273-284.

15 Римский В. Л. Бюрократия, клиентелизм и коррупция в России. Общественные науки и современность. 2014. № 6. С. 71.

${ }^{16}$ Нисневич Ю. А. Электоральная коррупция в России: политико-правовой анализ федеральных избирательных кампаний в 2003-2012 годах. Москва: Фонд «Либеральная миссия», 2014. C. 4. URL: http://www.liberal.ru/upload/files/Elektoralnaya\%20korrutsiya.pdf.
} 
of political corruption set, first and foremost, political goals, that is, the preservation, receipt, division, strengthening of state power as the highest form of political power; subjects of political corruption use methods and measures (abuse of office, access of official authorities, graft, bribery, etc.), for which penalties are provided for in the current criminal law ${ }^{17}$.

\section{The impact of certain forms of informal destructive political practices on democratic transit in the post-Soviet space}

One of the most common informal political practices and forms of «soft» corruption is «clientelism» (patron-client relations). As J. Scott notes, although actual use of the terms «patron» and «customer» is largely confined to the Mediterranean and Latin American regions, similar relationships can be found in most cultures and most clearly present in pre-industrial nations. Patron-client relationships can be defined as a separate type of dyadic communication (that is, involving two persons) using an instrumental friendship in which a person of higher socio-economic status (patron) uses his or her own influence and resources to provide protection or benefits to the individual lower status (client), which in turn reciprocates by offering general support and assistance, including personal services, to the patron ${ }^{18}$.

V. Rimsky gives the following definition of clientelism - «a social phenomenon characterized by the formation of relations of prepotance, domination and subordination, dependence and independence on the principle of patron-client. In this relationship, one party - the patron - is the protector and the other - the client - is patronized. The status of the parties to these relationships is very situational and changeable: patrons and clients are interdependent, and in some cases, for example, clients have the ability to force the patron to act in their interests, limiting their own» ${ }^{19}$.

In the system of patron-client relations, the more influential party (patron), who may occupy a high position in the system of government, provides «services» for the less status «client» in exchange for, for example, intangible benefits. Patronage is a distribution of resources by a ruling group

\footnotetext{
17 Тіньков А. Л. Запобігання і протидія політичній корупції в системі державного управління України: Автореф. дис. на здобуття наук. ступеня к-та наук $з$ держ. упр.: 25.00.02. Київ: Національна академія державного управління при Президентові України, 2013. C. 9. URL: http://academy.gov.ua/NMKD/library_nadu/Avtoreferat/32f72418-a3b6-4af99044-46f80c8aef29.pdf.

${ }^{18}$ Scott J. C. Patron-client Politics and Political Change in Southeast Asia. The American Political Science Review. 1972. № 1. Vol. 66. P. 92. URL: http://www.la.utexas.edu/ users/chenry/pmena/coursemats/2009/Scott-1972-clientelism.pdf.

${ }_{19}$ Римский В. Л. Бюрократия, клиентелизм и коррупция в России. Общественные науки и современность. 2014. № 6. С. 74.
} 
to attract election votes or other political support. Participation in patronclient relations is only partially voluntary and often imposed by the patron, acquiring the characteristics of «offer that can not be refused». According to the opinion of S. Barsukov, the patron-client relationship is «involuntary as a result of their hierarchical disposition, which measures the degree of dependence of the subjects and the range of exchangeable goods» ${ }^{20}$. Patronclient relationships are built on a kind of trust, which, however, is not universalistic.

Institutions of patronage are aimed, first and foremost, at achieving private (rather than group) goals rather than common goals and objectives for society. L. Roniger points out the «subversive» role of clientelism in relation to formal public institutions: «patrons and clients are not interested in equal relations or formal rules, their interest concerns specific individuals. They are not interested in setting general rules for all citizens, but rather in using specific situations for their own benefit. Thus, patron-client networks are used to abuse public resources» ${ }^{21}$.

Patron-client relationships can be spread across four levels: interpersonal personal; group (most often within tribal communities and clans - a phenomenon characteristic of traditional societies); at the state level as a whole (when patronage practices begin to play a significant role in the system of resource allocation, elite rotation and substitution mechanisms); supranational (international organizations and intergovernmental associations) ${ }^{22}$. The last two levels have the greatest danger for the processes of democratic transformation.

According to the opinion of M. Afanasyev, such relations are a kind of «airbag» in the conditions when political, financial or any other social upheavals occur, since their invariability is expressed in the peculiarities of functioning. Being held in a liberal democracy, patron-client relations are an indicator not only of the efficiency of the institutions of power, but also to some extent of social maturity and well-being of society ${ }^{23}$. Political connections and «trust receipts» form a different set of relationships between group members, forming interest groups and pressure groups whose origins cannot be explained by the official's functional responsibilities.

\footnotetext{
${ }^{20}$ Барсукова С. Ю. Реципрокные взаимодействия. Сущность, функции, специфика. Социологические исследования. 2004. № 9. С. 27.

21 Roniger L. Civil Society, Patronage and Democracy. International journal of comparative sociology. 1994. Vol. 35. № 3-4. P. 213.

22 Torsello D. Clientelism and Social Trust in Comparative Perspective: Particularism versus Universalism. International Journal of Humanities and Social Science. 2012. Vol. 2. № 23. P. 73-77.

23 Афанасьев М. Н. Клиентелизм: историко-социологический очерк Политические исследования (Полис). 1997. № 1. С. 162.
} 
Clientelism can take many forms. R. Kaufman points to the main characteristics of patron-client relationships: a) such relationships emerge between actors with unequal power and status, b) these relations are based on the principles of reciprocity; c) such relations are of a private nature and are to a small extent guided by public law or public norms ${ }^{24}$. L. Lomnitz believes that patron-client relationships are «a form of reciprocity in which clients benefit in exchange for loyalty and subordination to senior patrons ${ }^{25}$. Some researchers, such as $\mathrm{S}$. Barsukov, propose to distinguish reciprocity (as a special type of social integration - «exchange of gifts between members of the social horizontal network») from clientelism in a number of parameters, such as: specificity of coercion to this type of relationship, duration in time, degree of autonomy from formal institutes ${ }^{26}$.

The peculiarity of the reciprocity phenomenon is that the exchange occurs horizontally and is a manifestation of friendship and to some extent an equal exchange. Participants in this process are linked through formal ties, but the gift itself, in its essence, its signifance and value vary, depending on the context.

Some authors highlight patronage as a separate form of informal destructive political practices. While clientelism is more about the interpersonal relationships of two individuals with different status, patronage, in turn, is often attributed to the redistribution of resources to different groups by a person related to the state apparatus. According to the opinion L. Roniger, «clientelist agreements are built on asymmetric but mutually beneficial and time-limited transactions that underlie participants' access to various resources in a stratified society» ${ }^{27}$.

In the context of variations on the theme of the relationship between the patron and the client a significant and widespread practice during political transit is «favoritism» (from the Latin favor - mercy) - the appointment of services or the provision of resources to relatives, acquaintances, in accordance with belonging to a particular party, race, religion, sect, and

${ }^{24}$ Kaufman R. R. The Patron-Client Concept and Macro-Politics: Prospects and Problems. Comparative Studies in Society and History. 1974. Vol. 16. № 3. P. 295. URL: https://www.cambridge.org/core/journals/comparative-studies-in-society-andhistory/article/patronclient-concept-and-macropolitics-prospects-andproblems/479DDF41BB86BF811586783FD621604F.

${ }^{25}$ Lomnitz L. A. Informal Exchange Networks in Formal Systems: A Theoretical Model. American Anthropologist. 1988. Vol. 90. № 1. P. 45. URL: https://anthrosource. onlinelibrary.wiley.com/doi/abs/10.1525/aa.1988.90.1.02a00030.

${ }^{26}$ Барсукова С. Ю. Реципрокные взаимодействия. Сущность, функции, специфика. Социологические исследования. 2004. № 9. С. 20.

27 Roniger L. Civil Society, Patronage and Democracy. International journal of comparative sociology. 1994. Vol. 35. № 3-4. P. 211-212. 
other groups, which negatively affects the quality of public activity and promotes inefficient and unfair distribution of public resources among those with special access to public office.

As S. Paramonov notes: «The phenomenon of the favorite determines the roles that intuitively perform social actors (individuals, groups and communities), which are characterized by the «clutch» of informal ties and the creation of a single sanctioned field of action of surrounding individuals ${ }^{28}$. Favoritism is an opportunity for a career lift as well as a direct influence on the political situation. If most informal practices are shrouded in a veil of secrecy, then this phenomenon has some publicity: as a rule, the name of the favorite is on everyone's lips, and its role in the political process is well-known.

Favoritism, as a rule, causes a similar chain reaction: if a leader chooses to put in the top positions of their favorites, then they do the same, take to themselves the deputies of their already authorized persons - their favorites. There is a circular bail.

A particular form of favoritism is nepotism (from the Latin «Nepos», nepotis - grandson, nephew), when the leader prefers to nominate for the position of his relatives and next of keen. That is, nepotism is a system of power built on affinity.

A close to nepotism form of informal political practices is cronyism - a system of government that relies on relations between friends.

Cronyism has two forms of propagation - instrumental and relational. Instrumental cronyism aims at fulfilling tasks of a utilitarian nature and satisfying self-interest. The relational form of cronyism is based on partnerships, friendships, loyal and loyal attitude of the subordinate to the leader, which further develops into providing unreasonable advantage, benefits and profits, and also manifests in making unreasonable decisions ${ }^{29}$.

Cronyism and nepotism lead to such things as: big deals when concluding deals, appointing relatives for key posts, preferential purchases of personal property, access to hard currency and more. Control over these areas of business creates the preconditions for using them for corruption. The distribution of such benefits is carried out among a small group of elites and their families, who are expected to return in the form of bribes and other «thanks». Corruption in the family circle is not as big as trade bribes and patronage systems.

${ }^{28}$ Парамонова С. П. Антикризисные меры: «за» и «против» института фаворитизма. Вестник Пермского национального исследовательского политехнического университета. Социально-экономические науки. 2009. № 4. С. 148.

29 Діденко І. Непотизм, фаворитизм та кронізм як причини виникнення конфлікту інтересів. Підприємництво господарство $i$ право. 2017. № 8. С. 104 . URL: http://pgp-journal.kiev.ua/archive/2017/8/22.pdf. 
Nepotism and cronyism are most often manifested during:

- subsidies - public funds provided to a company or industry, in view of the need to adjust the market, which the government considers to be a «failure», enabling a company or industry to obtain more than ordinary conditions, profit or increase its profitability;

- refinancing when the government spends money to support a business that is having problems trying to counteract the consequences that these problems can cause;

- granting government loans or payments offered by the government on preferential terms to specific companies or industries;

- government setting tariffs (import or export tax, state-set prices, creating market barriers) that protect certain industries or businesses;

- securing special interests through abuse of law to approve and preserve business interests;

- in the phenomenon of "revolving doors», that is, the relationship between legislators or regulators and the industries they regulate, which imply the transition of persons employed by regulators to work in enterprises that they once regulated, and vice versa;

- licensing of professional activity - granting permission from a governing body that is required for a particular activity ${ }^{30}$.

Thus, we can talk about the interdependent status of favoritism, nepotism, cronyism as a relation of the whole and the part. All these privileged states are directly related to explicit («hard») corruption, but they cannot be identified.

The use of nepotism has led to the existence of clan relations. And it should be noted that this tendency is inherent in a number of post-Soviet countries. It significantly impedes the processes of democratic transit and even facilitates a reverse movement (to the formation of authoritarian tendencies).

The collapse of the Communist Party, the collapse of the USSR, and the subsequent political transit of the post-Soviet countries led to increased influence by regional elites pursuing their own goals, regardless of ties with formal institutions.

As a result of such processes, post-Soviet politics in a number of new states has acquired a clannish trait where leaders of large clans have authority not through high positions but through the ability to own and distribute economic and administrative resources among clan members. Thus, such leaders gained institutional status, and formal institutions were

30 Cronyism in America. Freedom Partners: website. URL: https://www.freedompartners.org/issues/cronyism-in-america/. 
often replaced by informal relationships. Clans in a number of post-Soviet countries have undermined legitimate state institutions and the power system as a whole ${ }^{31}$.

Therefore, it is crucial that administrative and other reforms in modern Ukraine aim at limiting and eliminating such destructive informal practices. Such measures will enhance the processes of democratization.

Consider this a form of informal political practice. The clan (a genus or related group related to economic and social ties) is the strongest form of solidarity of bloodline and patronage-client integration, the identification of individuals that has prevailed for millennia and has grown from a traditional primitive society. At the same time, it is the most dangerous and destructive form of elite grouping and recruiting for undeveloped democratic societies, since here the unifying basis of people are not personal properties and virtues, but casual biological and natural relations of affinity, nepotism, friendship, etc. As a result, the nation is weakened, divided into many competing families, tribes, their segregation, inequality and injustice, which lead to an ethnos of self-destruction.

Another form of «soft» corruption is localism or regionalism - activities aimed at securing wholly or mainly local, local interests at the expense of broader regional, interregional, nationwide, civic and other public interests ${ }^{32}$.

It should be noted that the term «localism» can be used to describe not only economic but also political corruption that produces separatism (Abkhazia, South Ossetia, Transnistria) and creates frozen conflicts. Ukraine has experienced in its experience this phenomenon in the Crimea and the Donbass, when with foreign military support from the Russian Federation in 2014 it led to catastrophic consequences: annexation of the Crimea and the war in the Donbass.

Tribalism is another form of informal destructive practices that significantly exacerbates authoritarianism in many post-Soviet countries). It has many manifestations: patronage of the representatives of his tribe in the state apparatus, low level of ethnic processes, tribal enmity, desire to deal only with representatives of his tribe ${ }^{33}$. Earlier the term was used in relation to Africa and Oceania, and nowadays it is often referred to as the practice of public relations in the territory of post-Soviet Central Asia.

31 Шкель С. Н. Неформальные институты в политическом процессе постсоветских государств. Фундаментальные исследования. 2014. № 12. С. 1585.

32 Сулакшин С. С., Максимов С. В., Ахметзянова И. Р. Государственная политика противодействия коррупции и теневой экономике в России. Монография в 2-х томах. T. 1. Москва: Научный эксперт, 2008. URL: http://rusrand.ru/files/books/ Protivod_Korrupcii_T1.pdf.

33 Дадабаева 3. Партийно-политическая система в Узбекистане, Таджикистане и Туркменистане. Россия и мусульманский мир. 2008. № 12 (198). С. 78. 
Political tribalism involves the penetration of certain ethnic groups related to tribal principles into public authorities and their influence on decisions at national and local levels ${ }^{34}$. It should be noted that such influence is exercised in the interests of these groups.

The transition from clan, tribalism and localism to particularism (regionalism) and separatism occurs quite naturally as the necessary conditions mature and (consciously or unconsciously) weaken legitimate forms of public communication. Legislative introduction of the concept of normative (mandatory) ethnic (national) proportional representation in the authorities (both local and state) is practiced in many countries) ${ }^{35}$.

An example of this phenomenon is the experience of a number of postSoviet countries, such as Kazakhstan, where according to 2000 data, the Senior Zhuz controlled 23, the Medium - 13, and the Junior - 6 senior state posts. Natives of the Senior Zhuz were the President, the Prime Minister, the President of the Presidential Administration, the Speaker of the Lower House of Parliament (Majilis), the National Security Committee, the Customs Committee, the Central Election Commission, the Minister of Defense, Foreign Affairs and others. ${ }^{36}$ As a result, the level of representation of the Middle Zhuz in the authorities decreased significantly, and the Junior Zhuz was pushed to the political periphery.

Within the Senior Zhuz, the closest environment (the «family») was dominated by N.A. Nazarbayev, which included his daughter Dariga, who controlled up to $90 \%$ of the country's information space through the media holding «Khabar» («News»); her husband, the son-in-law of President Rakhat Aliyev, who chaired the National Security Committee during this period; nephew Kairat Satibaldi and second son-in-law Timur Kuleybaev, who respectively managed KazakhOil and KazakhTransoil corporations ${ }^{37}$. According to the Expert magazine for 2006, all economic assets, except the oil industry, were consolidated within the ruling clan. The approval of the

34 Кыдыралиева М. Р. Трайбализм как социальное явление (на материалах Кыргызстана): автореф. дисс. на соискание уч. степени к-а филос. наук: 09.00.11. Бишкек, 2015. C. 9. URL: http://cslnaskr.jet.kg/collections/uploads/Автореферат_Кыдыралиева\%2 0Миргул\%20Рысбаевна.pdf.

35 Сулакшин С. С., Максимов С. В., Ахметзянова И. Р. Государственная политика противодействия коррупции и теневой экономике в России. Монография в 2-х томах. T. 1. С. 72-80. Москва: Научный эксперт, 2008. URL: http://rusrand.ru/files/books/ Protivod_Korrupcii_T1.pdf.

${ }^{36}$ Амрекулов Н. Жузы в социально-политической жизни Казахстана. Центральная Азия $u$ Кавказ. 2000. № 3(9). URL: https://www.ca-c.org/journal/cac-092000/16.Amrek.shtml.

${ }^{37}$ Власть в Центральной Азии: семьи, кланы, жузы [12.07.2006]. Радио Свобода. 2001. 26 июля. URL: http://www.svoboda.org/programs/RT/2001/RT.072601.asp. 
«family» was required by all major business projects implemented in the republic ${ }^{38}$.

Tribalism in Turkmenistan is most clearly expressed in the rivalry of the clans of the Ahal Oasis, in which Ashgabat is located, with clans of other regions.

Genetically, every Turkmen tribe (about 30 of them and more than 5,000 generic groups) is a fairly tight, distinct subpopulation. The Nation of Tribes is made up of ethnographic groups so divided that each one can, in principle, be referred to as an independent small nation ${ }^{39}$.

The most striking examples of tribalism in Turkmenistan include the following: 1) in December 2015, authorities banned entry to the capital of non-urban vehicles; 2) in 2016, de jure, the President of Turkmenistan secured the requirement to streamline the system of renting apartments in Ashgabat (most of the tenants are representatives of other regions, that is, other Turkmen tribes, as a result, they were simply evicted from the rented apartments), etc. ${ }^{40} ; 3$ ) the leaders of the republic carried out a personnel policy of support to the representatives of their tribe. Only when the head of state changed, did his environment, practically the whole administrative apparatus, change; since Niyazov's time there has been a practice of appointing heads of regions and regional units of law enforcement agencies, representatives of Ashgabat, rather than locals.

\section{Destructive factors of democratic transit in Ukraine: forms of manifestation and ways of overcoming them}

According to Ukrainian political analyst Ivan Symonenko, the process of society's tribalization is a disturbing symptom of entering into socialcivilizational backwardness ${ }^{41}$. The absence in the society of civilized rotation of personnel is replaced by a number of assignments defined by nepotism, localism, tribalism in an environment of purely personal relations.

The state of social consciousness can create prerequisites for the development of favoritism and nepotism, when the level of trust in formal

\footnotetext{
${ }^{38}$ Шустов А. Постсоветский трайбализм - клановые элиты стран Центральной Азии. ЦентрАзия: веб-сайт. URL: http://www.centrasia.ru/news2.php?st=1208944620.

${ }^{39}$ Грозин А. Элиты Туркменистана и центральноазиатские кланы: общее, особенное и трудности модернизации. Азия $u$ Африка сегодня. 2010. №9. URL: http://www.perspektivy.info/print.php?ID=72647.

40 Нарастающий трайбализм. Хроника Туркменистана: веб-сайт. URL: https://www.hronikatm.com/2016/02/narastayushhiy-traybalizm/.

${ }^{41}$ Модернизация и трайбализация на постсоветском пространстве: вместе или врозь? Информационное агентство ИА REX: веб-сайm. URL: http://www.iarex.ru/articles/ 11890.html.
} 
institutions and the level of interpersonal trust in the state and society are very low.

Nepotism and cronyism often lead to the artificial creation of management positions and even entire departments for relatives. Favorites may not be available for long periods of time, be responsible for anything, be transferred to subordinates, while receiving much higher salaries than salaries. This reduces the level and quality of management, creates artificial obstacles to development.

Therefore, the establishment of an independent Ukraine, first of all, required combating similar phenomena, which reflects the legislation.

Ukrainian legislation, for example, Art. $25^{1}$ of the Labor Code of Ukraine as of $07.01 .2017^{42}$ or Art. 32 of the Law of Ukraine «On Civil Service» of 10.12.2015 (as of 05.01.2017) ${ }^{43}$ etc., implies restriction of joint work of relatives and next of keen in one enterprise, in one institution or organization. However, statutory restrictions on the joint work of relatives primarily relate to positions of direct subordination, control or dependence and work related to the ability to make decisions regarding other businesses where close relatives of an official work. That is, a person can be recruited to another department, administration, division, unit, etc. The procedure for imposing such a restriction on state-owned enterprises shall be established by law. And in non-state-owned enterprises, such restrictions are imposed by the owners at their discretion ${ }^{44}$.

The use of nepotism leads to the formation of clan relations. Representatives of different political forces are often linked by family ties, which transforms the hierarchy of the political system into a «tangle» of confusing family ties, which does not contribute to the effectiveness of representative institutions, including political parties ${ }^{45}$. Domestic researchers say that favoritism, nepotism, blat, patronage and clientelism, bribes and

\footnotetext{
${ }^{42}$ Кодекс законів про працю України: Закон України від 10.12.1971 р. № 322-VIII (ред. від 07.01.2017 р.). Офіиійний сайт Верховної Ради Украйни. URL: http://zakon3.rada.gov.ua/laws/show/322-08.

43 Про державну службу: Закон України від 10.12.2015 № 889-VIII (ред. від 05.01.2017). Офіиійний сайт Верховної Ради Украйни. URL : http://zakon5.rada.gov.ua/laws/show/889-19.

${ }^{44}$ Сахань О. М. Проблема непотизму в сучасному українському суспільстві. Вісник Національного університету «Юридична академія України імені Ярослава Мудрого». 2017. № 2(33). C. 191.

45 Політологія: сучасні терміни і поняття. Короткий навчальний словник-довідник для студентів ВН3 I-IV рівнів акредитації. 3-тє вид., випр. і доп. Уклад.: В. М. Піча, наук. ред. Л. Д. Климанської, Я. Б. Турчин, Н. В. Хоми. Львів: Новий світ-2000, 2014. С. 255-256.
} 
bribery and trade in influence were among the most common forms of corruption transactions during $1991-2013^{46}$.

The practice of combating nepotism as a threatening phenomenon for democratic development has been appropriately enshrined in international legal acts. The UN Convention against Corruption ${ }^{47}$ nepotism is considered a manifestation of corruption that harms society and the state. Nepotism is defined by a person's acquisition of new positions or advantages not because of his / her high professional abilities, but because of his / her involvement in a certain social environment.

National legislation also contains rules aimed at preventing corruption and other informal political practices. Thus, the Law of Ukraine «On Prevention of Corruption» (Article 27 «Restrictions on the Collaborative Work of Close Persons») states that persons applying for positions are obliged to inform the management of the authority in the position in which they are applying about employees of the body close to them ${ }^{48}$. The provisions of the Laws of Ukraine «On Civil Service» are also aimed at combating nepotism (Article 12) ${ }^{49}$ and «On Local Government Service» (Article 12) ${ }^{50}$. By «close persons» the law refers to «spouses, children, parents, siblings, grandparents, grandchildren, adoptive parents, adoptive parents, as well as others connected by common life and have mutual rights and obligations ${ }^{51}$.

An example of nepotism in Ukraine, some analysts called the personnel policy of the President of Ukraine V. Yushchenko, which was based on the emotions and desires of the first person of the state and its environment ${ }^{52}$. As a result, the phrase «beloved friends» has become widespread in the Ukrainian political discourse to refer to a managerial system with

\footnotetext{
${ }^{46}$ Копистира А. М. Типологія корупції в Україні. Інноваційна економіка. 2013. № 8. C. 43-46. URL: http://www.nbuv.gov.ua/j-pdf/inek_2013_8_8.pdf.

${ }^{47}$ Конвенція ООН проти корупції. Офіційний сайт Верховної Ради України. URL: http://www.zakon1.rada.gov.ua/laws/show/995_c16.

${ }^{48}$ Про запобігання корупції: Закон України від 14.10.2014 № 1700-VII. Офіиійний сайт Верховної Ради України. URL: http://zakon5.rada.gov.ua/laws/show/1700-18.

49 Про державну службу: Закон України від 10.12.2015 № 889-VIII (ред. від 05.01.2017). Офіиійний сайт Верховної Ради Украӥни. URL: http://zakon5.rada.gov.ua/laws/show/889-19.

${ }^{50}$ Про службу в органах місцевого самоврядування: Закон України від 07.06.2001 № 2493-III. Офіційний сайт Верховної Ради Украйни. URL: http://zakon3.rada.gov.ua/laws/show/2493-14.

51 Рабінович С. Неформальні практики публічної влади як форма дії фактичної конституції. Вісник Національної академії правових наук України. 2013. № 3 (74). С. 108116. URL: http://www.nbuv.gov.ua/j-pdf/vapny_2013_3_16.pdf.

52 Дорош Л., Івасечко О. Непотизм як політико-правова проблема українського державотворення. Humanitarian vision. 2015. Vol. 1. Num. 1. C. 16. URL: http://nbuv.gov.ua/UJRN/hv_2015_1_1_5.
} 
widespread nepotism and clientele associated with the head of state. Therefore, the declared requirements for management personnel, such as professionalism, patriotism and integrity, have been sidelined. At the forefront were those who matched the main and most essential characteristic of any candidate for leadership - belonging to "theirs», which should outweigh all other characteristics and virtues ${ }^{53}$. During the rule of $\mathrm{V}$. Yanukovych in the political and economic system of Ukraine, a specific personalized entity, which in the information and analytical publications is designated as the Presidential «Family» ${ }^{54}$. Directly family and steady friendships, or time-tested business relationships, have become the sole criteria for selection in personnel policy. Therefore, the management of V. Yanukovych's presidency was completely controlled by relatives solely for the benefit of the «family».

Investigating how such informal practices affect policy effectiveness in the country is difficult, but one can say that such a «web» significantly slows down the movement to democracy, reducing people's trust in formal institutions and their desire for effective support for social reform. This breeds disbelief in social elevators and transparent competitions, creating the belief that the position will be occupied by relatives or godfathers of the dismissed person under any circumstances. And so, there is a brain drain, narrowing democratic prospects. Unfortunately, such negative practices are still present in Ukrainian politics, according to the researchers of personnel policy of different national leaders ${ }^{55}$.

Consequently, the presence of such processes contributes to the emergence of corruption within any sphere, and the mechanism of horizontal spread contributes to an increase in the number of corruption crimes. This process will continue until the sphere of corruption is completely affected ${ }^{56}$.

The effect of the spread of corruption, similar to disease, is expressed in its overall multiplication by increasing the number of corruption equipment and persons involved in it, is called contagiousness. It occurs both at the micro level - between individuals within the «closed» system and at the macro level - between regions, countries, etc.

\footnotetext{
53 Лосєв І. Симулякри української демократії. Український тиждень. 2011. 3 червня. URL: http://www.tyzhden.ua/Politics/23922.

54 Рабінович С. Неформальні практики публічної влади як форма дії фактичної конституції. Вісник Національної академї правових наук України. 2013. № 3 (74). C. 108-116. URL: http://www.nbuv.gov.ua/j-pdf/vapny_2013_3_16.pdf.

55 Малко Р. Мандат у спадок. Украйнський тиждень. 2014. 24 жовтня. URL: http://www.tyzhden.ua/Politics/121928.

${ }^{56}$ Борцев В. В. Коррупция : контагиозность, последствия и методы противодействия: дисс...канд. экон. н.: 08.00 .01 (01). Москва, 2014. С. 27-31.
} 
Macro-level contagiousness is expressed in the spread of corruption across regional boundaries and is called inter-regional contagiousness. It arises for three reasons: processes of globalization and widespread business activity have led to a high level of integration, which is why there is a high likelihood of corruption among individuals with intense business contacts; the spread of corruption is possible through cross-border organized crime activities; formed opinion on the actual extent of corruption by citizens of one region generates their expectations for future growth. Corruption is transmitted to citizens of other countries due to social inter-regional interactions ${ }^{57}$.

In 2009, a cross-country survey was conducted in 123 countries $^{58}$. It has shown that the scale of the contagiousness effect of corruption is decreasing with increasing geographical distance. And, importantly, the contagious effect turned out to be just and in the opposite direction, that is, with the reduction of corruption in one of the countries, there are corresponding changes in the neighboring countries. A key determinant of the spread of corruption, as the results of the study prove, was close political contact.

The phenomenon of contagiousness of corruption is a relatively new trend in the field of studying the basic phenomenon of corruption. There is every reason to believe that there is a direct effect of the spread of corruption both between territorial entities within the country and between neighboring countries.

The decisive factor in the latter case is the proximity of the characteristics of the institutional environments or the commonality of the identified political culture. Thus, intergovernmental contagiousness of corruption is more likely to occur in the event of additional unifying institutional, political or economic characteristics.

An effective anti-corruption policy is a prerequisite for overcoming the contagious effect of corruption (both «hard» and «soft»). Here it is necessary to agree with I. Myloserdna that the necessary steps of such a policy are: becoming a society as an equal partner in the development and implementation of the national strategy for combating corruption; involvement of various civil society institutions in anti-corruption counteraction $^{59}$. However, in our view, it is precisely because of the effect of contagiousness that not only civil society institutions within the state but

${ }^{57}$ Becker S., Egger P., Seidel T. Common political: Evidence on regional corruption contagion. European Journal of Political Economy. 2009. 25 (3). P. 300-310.

${ }^{58}$ Ibid.

${ }^{59}$ Милосердна І. М. Участь громадянського суспільства у протидії корупції:досвід країн Центрально-Східної Європи. Політичне життя. 2019. № 3. С. 41. 
also the structures of global civil society need to be involved in cooperating in the sphere of overcoming certain informal destructive political practices.

\section{CONCLUSIONS}

Thus, at the present stage, the use of informal destructive political practices is a significant threat to democratic transformations, a prerequisite for the hybridization of the political regime and the reverse movement of transformation processes toward authoritarianism.

Therefore, given the negative experience of several countries, Ukraine needs to pursue a policy of preventing nepotism, favoritism, cronyism, tribalism and other forms of «soft» corruption in order to prevent political conflicts and successfully democratize society.

Investigating the phenomenon of the contagiousness of corruption leads to the conclusion that only close cooperation and exchange of experience between countries will allow to combat effectively informal destructive political practices, since reducing their manifestations in one country will facilitate similar processes in neighboring countries.

As shown by the analysis, informal relationships, which are a deviation from the norm and can cause significant damage to the political system and society as a whole, at the same time appear to be a form or a way of «smoothing» conflicts between the norms of various kinds and rational law. They are able to correct temporarily the shortcomings of socio-political institutions, allowing some of them relatively adequately, functionally, to work. However, appropriate formal practices aimed at democratization must finally be established and implemented.

An effective anti-corruption policy is one way of overcoming informal destructive political practices, one of which should be to limit the spread of such practices. It is based on two basic conditions, the neglect of which makes the implementation of any initiative absolutely fruitless: the manifestation of the strongest political will and the unambiguous and undisputed rule of law and uniformity of law for each and everyone.

The negative effects of these phenomena require not only the development of means of combating corruption, but also changes in the political consciousness of society in order to prevent the effects of both «hard» and «soft» corruption in the contagious (rapid) effect; to destroy established practices of lobbying of individual and group interests, decisionmaking for the benefit of persons empowered with power or their environment. In our country, such changes will reduce manifestations of policy hybridization and accelerate transformation processes on the path of democratization. 
The constructive socio-political changes necessary for political transit towards democracy, able to combine the formal and the positive informal, can be combined in the concept of «parity democracy». Building such a model of democracy is the key to democratic transit, providing equal rights and equal opportunities for all policy makers.

At the present stage of social development, the problem of achieving parity in society remains urgent in many countries. Despite the theoretical research, in the practical plane the situation is determined by a high degree of negative dynamics and manifestations of mass public dissatisfaction with the actions of the authorities. Today, we see this even in the example of many developed European countries. Sometimes tension is inspired not only by the presence of internal factors, but also by external interventions through the use of negative informal practices such as corruption, falsified or false information on social networks, etc. All this requires constant attention and effective control by the state and society and a clear awareness of both the positive and the negative aspects of the combination of formal and informal in the political process, above all, during the phase of democratic transit.

\section{SUMMARY}

Constructive and destructive factors of democratic transit are considered. The concept and essence of informal political practices are analyzed, the main approaches to their definition are considered. The criteria for the typology of such practices are clarified, their constructive and destructive forms are determined. The division of informal destructive political practices into corruption («hard» corruption) and other forms («soft» corruption) is justified. Forms of «soft» corruption include clientelism, patronage, favoritism, nepotism, cronyism, lobbying, clannishness, localism, political tribalism and others. The analysis of manifestations of such forms of informal destructive political practices as favoritism, nepotism, cronyism, clanism and tribalism in the post-Soviet space is analyzed. The essence of the effect of the contagiousness of corruption is found out. Two groups of post-Soviet countries are identified with differences in prevalent forms of «soft» corruption. It is proved that in the western republics of the former USSR individual practices prevail (clientelism, favoritism, nepotism and cronyism), in the eastern regions - collective (clan and tribalism). It is justified that to create effective mechanisms for overcoming all forms of informal destructive political practices, taking into account the effect of contagiousness, is possible only if a model of parity democracy is built in Ukraine. 


\section{REFERENCES}

1. Becker S., Egger P., Seidel T. Common political: Evidence on regional corruption contagion. European Journal of Political Economy. 2009. 25 (3). P. 300-310.

2. Cronyism in America. Freedom Partners: website. URL: https://www.freedompartners.org/issues/cronyism-in-america/.

3. Helmke G., Levitsky S. Informal Institutions and Comparative Politics: A Research Agenda. Perspectives on Politics. 2004. Vol. 2. Issue 04. P. 725-740. URL: https://wcfia.harvard.edu/files/wcfia/files/ 883_informal-institutions.pdf.

4. Karklins R. Typology of Post-Communist Corruption. Problems of Post-Communism. 2002. Vol. 49. № 4. P. 22-32. URL: http://pdc.ceu.hu/archive/00001528/01/03Karklins\%5B1\%5D.pdf.

5. Kaufman R. R. The Patron-Client Concept and Macro-Politics: Prospects and Problems. Comparative Studies in Society and History. 1974. Vol. 16. № 3. P. 284-308. URL: https://www.cambridge.org/core/journals/ comparative-studies-in-society-and-history/article/patronclient-concept-andmacropolitics-prospects-and-problems/479DDF41BB86BF81 1586783FD621604F.

6. Lauth H.-.J. Informal Institutions and Democracy. Democratization. 2000. Vol. 7. № 4. P. 27-43.

7. Lomnitz L. A. Informal Exchange Networks in Formal Systems: A Theoretical Model. American Anthropologist. 1988. Vol. 90. № 1. P. 42-55. URL: https://anthrosource.onlinelibrary.wiley.com/ doi/abs/10.1525/aa. 1988.90.1.02a00030.

8. Roniger L. Civil Society, Patronage and Democracy. International journal of comparative sociology. 1994. Vol. 35. № 3-4. P. 207-220.

9. Scott J. C. Patron-client Politics and Political Change in Southeast Asia. The American Political Science Review. 1972. № 1. Vol. 66. P. 91113. URL: http://www.la.utexas.edu/users/chenry/pmena/coursemats/2009/ Scott-1972-clientelism.pdf.

10. Torsello D. Clientelism and Social Trust in Comparative Perspective: Particularism versus Universalism. International Journal of Humanities and Social Science. 2012. Vol. 2. № 23. P. 73-77.

11. Амрекулов Н. Жузы в социально-политической жизни Казахстана. Центральная Азия и Кавказ. 2000. № 3(9). URL: https://www.ca-c.org/journal/cac-09-2000/16.Amrek.shtml.

12. Афанасьев М. Н. Клиентелизм: историко-социологический очерк (II). Политические исследования (Полис). 1997. № 1. С. 157-166. 
13. Барсукова С. Ю. Реципрокные взаимодействия. Сущность, функции, специфика. Социологические исследования. 2004. № 9. С. 20-29.

14. Борцев В. В. Коррупция : контагиозность, последствия и методы противодействия: дисс...канд. экон. н.: 08.00 .01 (01). Москва, 2014. $151 \mathrm{c}$.

15. Будко Д. А. Политические практики взаимодействия органов региональной власти в современной России: дисс... канд. полит. н.: 23.00.02. Санкт-Петербург, 2014. 192 с. URL: https://disser.spbu.ru/ disser2/disser/Dissertazija_BudkoDA.pdf.

16. Власть в Центральной Азии: семьи, кланы, жузы [12.07.2006]. Радио Свобода. 2001. 26 июля. URL: http://www.svoboda.org/programs/ RT/2001/RT.072601.asp.

17. Грозин А. Элиты Туркменистана и центральноазиатские кланы: общее, особенное и трудности модернизации. Азия и Африка сегодня. 2010. № 9. URL: http://www.perspektivy.info/ print.php?ID=72647.

18. Дадабаева 3. Партийно-политическая система в Узбекистане, Таджикистане и Туркменистане. Россия и мусульманский мир. 2008. № 12 (198). С. 78-102.

19. Діденко I. Непотизм, фаворитизм та кронізм як причини виникнення конфлікту інтересів. Підприємництво господарство $i$ право. 2017. № 8. C. 103-106. URL: http://pgp-journal.kiev.ua/archive/2017/8/22.pdf.

20. Дорош Л., Івасечко О. Непотизм як політико-правова проблема українського державотворення. Humanitarian vision. 2015. Vol. 1. Num. 1. C. 13-20. URL: http://nbuv.gov.ua/UJRN/hv_2015_1_1_5.

21. Кармазіна М., Шурбована О. «Інститут» та «інституція»: проблема розрізнення понять. Політичний менеджмент. 2006. № 4. C. $10-19$.

22. Кодекс законів про працю України: Закон України від 10.12.1971 р. № 322-VIII (ред. від 07.01.2017 р.). Офіційний сайт Верховної Ради Украӥни. URL: http://zakon3.rada.gov.ua/laws/show/322-08.

23. Конвенція ООН проти корупції. Офіиійний сайт Верховної Ради України. URL: http://www.zakon1.rada.gov.ua/laws/show/995_c16.

24. Копистира А. М. Типологія корупції в Україні. Інноваційна економіка. 2013. № 8. C. 43-46. URL: http://www.nbuv.gov.ua/jpdf/inek_2013_8_8.pdf.

25. Кормич Л. І., Краснопольська Т. М. Основні напрями стратегії впровадження моделі паритетної демократії в сучасній Україні. Актуальні проблеми політики. 2018. Вип. 62. С. 6-26. 
26. Коррупция: политические, экономические, организационные и правовые проблемы. Ред. В. В. Лунеева. Москва: Юристь, 2001. 426 с.

27. Кыдыралиева М. Р. Трайбализм как социальное явление (на материалах Кыргызстана): автореф. дисс. на соискание уч. степени к-а филос. наук: 09.00.11. Бишкек, 2015. URL: http://cslnaskr.jet.kg/ collections/uploads/Автореферат_Кыдыралиева\%20Миргул\%20Рысбаев на.pdf.

28. Лосєв I. Симулякри української демократії. Украӥнський тиждень. 2011. 3 червня. URL: http://www.tyzhden.ua/Politics/23922.

29. Малко Р. Мандат у спадок. Український тиждень. 2014. 24 жовтня. URL: http://www.tyzhden.ua/Politics/121928.

30. Мамчуева Ф. Ю. Формальные и неформальные политические практики современного политического процесса. Историческая $u$ социально-образовательная мисль. 2013. № 5(21). С. 150-153.

31. Меркель В., Круассан А. Формальные и неформальные институты в дефектных демократиях. Полис. 2002. № 2. С. 20-30.

32. Милосердна I. М. Участь громадянського суспільства у протидії корупції:досвід країн Центрально-Східної Свропи. Політичне життя. 2019. № 3. С. 37-43.

33. Модернизация и трайбализация на постсоветском пространстве: вместе или врозь? Информационное агентство ИА REX: веб-сайт. URL: http://www.iarex.ru/articles/11890.html.

34. Нарастающий трайбализм. Хроника Туркменистана: вебcaüm. URL: https://www.hronikatm.com/2016/02/narastayushhiytraybalizm/.

35. Нисневич Ю. А. Электоральная коррупция в России: политико-правовой анализ федеральных избирательных кампаний в 2003-2012 годах. Москва: Фонд «Либеральная миссия», 2014. 204 с. URL: http://www.liberal.ru/upload/files/Elektoralnaya\%20korrutsiya.pdf.

36. Парамонова С. П. Антикризисные меры: «за» и «против» института фаворитизма. Вестник Пермского национального исследовательского политехнического университета. Социальноэкономические науки. 2009. № 4. С. 146-172.

37. Подхомутникова М. В. Неформальные политические практики в современной России: субъекты институционализации: автореф. дисс. на соискание уч. степени к-та полит. н.: 23.00.02. Краснодар, 2010. 27 c. URL: http://cheloveknauka.com/v/ 335868/a?\#?page $=27$.

38. Політологія: сучасні терміни і поняття. Короткий навчальний словник-довідник для студентів ВНЗ I-IV рівнів акредитації. 3-те вид., 
випр. і доп. Уклад.: В. М. Піча, наук. ред. Л. Д. Климанської, Я. Б. Турчин, Н. В. Хоми. Львів: Новий світ-2000, 2014. 516 с.

39. Про державну службу: Закон України від 10.12.2015 № 889-VIII (ред. від 05.01.2017). Офіиійний сайт Верховної Ради України. URL : http://zakon5.rada.gov.ua/laws/show/889-19.

40. Про запобігання корупції: Закон України від 14.10.2014 № 1700-VII. Офіційний сайт Верховної Ради Украӥни. URL: http://zakon5.rada.gov.ua/laws/show/1700-18.

41. Про службу в органах місцевого самоврядування: Закон України від 07.06.2001 № 2493-III. Офіційний сайт Верховноӥ Ради України. URL: http://zakon3.rada.gov.ua/laws/show/2493-14.

42. Рабінович C. Неформальні практики публічної влади як форма дії фактичної конституції. Вісник Національної академї правових наук України. 2013. № 3 (74). С. 108-116. URL: http://www.nbuv.gov.ua/j-pdf/vapny_2013_3_16.pdf.

43. Римский В. Л. Бюрократия, клиентелизм и коррупция в России. Общественные науки и современность. 2014. № 6. С. 65-84.

44. Сахань О. М. Проблема непотизму в сучасному українському суспільстві. Вісник Національного університету «Юридична академія України імені Ярослава Мудрого». 2017. № 2(33). С. 189-209.

45. Сулакшин С. С., Максимов С. В., Ахметзянова И. Р. Государственная политика противодействия коррупции и теневой экономике в России. Монография в 2-х томах. Т. 1. Москва: Научный эксперт, 2008. URL: http://rusrand.ru/files/books/Protivod_Korrupcii_ T1.pdf.

46. Суханов В. А. Коррупция в органах государственной власти как глобальная проблема. Вестник МГИМО. 2013. № 4(31). С. 212-218.

47. Тіньков А. Л. Запобігання і протидія політичній корупції в системі державного управління України: Автореф. дис. на здобуття наук. ступеня к-та наук 3 держ. упр.: 25.00.02. Київ: Національна академія державного управління при Президентові України, 2013. 23 с. URL: http://academy.gov.ua/NMKD/library_nadu/Avtoreferat/32f72418a3b6-4af9-9044-46f80c8aef29.pdf

48. Хутов К. М. Лоббирование, коррупция, монополизм: исследование криминогенного взаимовлияния. Преступность $u$ коррупция: современные российские реалии: сборник научных трудов / под ред. Н. А. Лопашенко. Саратов: Сателлит, 2003. С. 273-284.

49. Циганов В. «Загроза політичної корупції у демократичних політичних режимах». Аналітична записка. Національний інститут стратегічних досліджень. URL: http://old2.niss.gov.ua/articles/882/.

50. Шкель С. Н. Неформальные институты в политическом процессе постсоветских государств. Фундаментальные исследования. 2014. № 12. C. 1582-1585. 
51. Шустов А. Постсоветский трайбализм - клановые элиты стран Центральной Азии. ЦентрАзия: веб-сайт. URL: http://www.centrasia.ru/news2.php?st=1208944620.

\section{Information about the author:}

Krasnopolska T. M.,

$\mathrm{PhD}$ in Political Sciences, Associate Professor, Associate Professor at the Department of Political Theories of the National University «Odessa Law Academy»

2, Academichna str., Odesa, 65009, Ukriane 